Original article

\title{
LAZY, SLEEPY AND BLIND DOORKEEPERS IN ANCIENT EGYPTIAN ART
}

\author{
El-Sayyad E. \\ Lecturer History \& Archaeology dept. Faculty of Arts. Alexandria Univ., Egypt
}

E-mail: emadelsayyad@hotmail.com

\begin{abstract}
Unusual phenomenon related with doorkeepers and guards in ancient Egyptian art, which depicted them as blind or sleep in the new kingdom tomb's scenes, so it reflected to literature cases. most scholars refer to it as kind of cynical art or a comic art. While others doesn't attract it their sights. In fact, this repeated scenes didn't happen by chance, but it necessary had a certain mean in the think of ancient Egyptian especially he represented this phenomenon by many styles, once as blind doorkeeper, and others as lazy or sleepy. the beginning of this phenomenon was at new kingdom and afterwards, so it may be related with some ideas known in the book of the dead.
\end{abstract}

Keywords: Door keeper, Guard, Gates, Book of the death, Blind

\section{Introduction}

The depicted or inscribed scenes on the walls of tombs in ancient Egypt are a historic and cultural record, which the owners used pictures to express about the funeral means, which became a major source of which we could identify the features and details of daily life. These scenes do not visualize the nature of the Egyptian's life only, but they have always been the major source for researchers to get to know their thoughts and beliefs after death in that world, which is still a mystery for us [1]. So, no wonder to see it has depicted the superstitious animals and Semi-human beings while they are doing multiple activities which can be summarized in how to act and receive the deceased in the other world consistent with what his mind could contemplate and realize [2]. It is noticeable that there is a big difference between the recorded scenes in the tombs of individuals and by other side which is depicted in the royal tombs. If the first combine between the scenes of daily life of the deceased among his/her family doing various activities of life, and also the scenes of the other world starting from the Funeral rituals and Pilgrimage tours to Abydos [3]. The views of all the royal tombs - especially in the time of the New Kingdom- depicted the journey of the king to the other world and the stages of it without referring to any mundane topics [4]. So, the studies that relate to the daily life in ancient Egypt paid attention to the scenes of the individuals tombs, because it shows multiple scenes of various activities in various fields. Also among these scenes there was a phenomenon that drew the attention of the researcher and can be described as a strange and un logical, because of its incompatibility with reality or its impossibility to occur, this is the scenes that depicts the doorkeepers in the ancient Egyptian art. 


\section{The Depiction of Doorkeepers and Their Actual Life}

It seemed to the researcher that the artist in the New Kingdom was getting used to depict these guards either in a state of amusement from work -guarding- or sleeping, but the most surprising thing is that the doorkeeper could be blind. Some researchers trying to provide an explanation for these scenes, each separated from one to the other, as it is a kind of cynical art or a comic art [5]. Maybe it is true if it happened once or even twice, or it appears in any of the professions and other crafts; but in fact this scene with its multiple cases was repeated in several views which is confined to that profession or that job that requires an amount of vigilance and activity. What makes this issue more important is that this phenomenon didn't happen in the tombs scenes only, but it had a very important presence in the literary texts, which increased the need to study this phenomenon, especially as it came in seriously context, away from the sarcasm or comical. It should be noted here, and before reviewing the scenes or the texts on this phenomenon that the position and value of the Doorkeepers in the ancient Egyptian life, so this profession in fact was never considered as one of the menial jobs which led the owners been ashamed of doing it. The opposite was right, there are many Doorkeepers had carried the title "Herald court" and they were closely linked with courts and judges [6]. In addition the listings of the workers which includes the pensions and wages since the Old Kingdom, was the best proof of the position and the value of the doorkeepers that exceeded the position and the value of both workers and servants, where the guards occupied the first places in the payroll, as well as their distinguish in wages and pensions in quantitative term [7]. However, this was not during the golden age of ancient Egyptian civilization which was known as "Pyramids builders period" only, but we can see the same case in the New kingdom in the village of workers in "Dier el Madineh", this village which included from the social pyramid all its spectrums, we find in the payroll that the doorkeepers had the highest share than the workers themselves, and it was their responsibility to collect taxes and the supervision of the warehouse property, that's what gave them laudable social status within the village [8]. The famous Literary text known as "Satire of the trades" that is attributed to "Khitti son Duauef" provides us with a very important spectacle which presents a picture of the doorkeeper in a position and status higher than the worker who was working under his supervision and control, so that the worker found himself forced to satisfy the doorkeeper by giving him some food as bribery [9] to allow him to go out, as following:

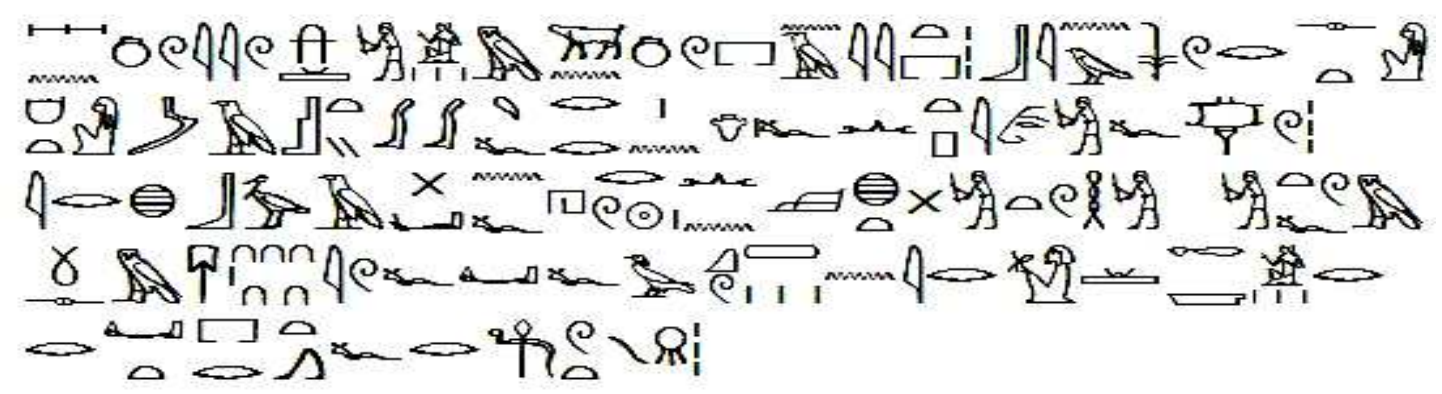

kny $m$ hnw-nзyt bin sw r st-hmt

M3sty. $\bar{f} r$ r $3-i b$. f $n$ pti . n. $f \underline{t} 3 w$

Ir hbi. n.f hrw nn sht hwi.tw. fm

ššm 50 iw. $f$ di.f $f$ kw $n$ iry- ${ }^{3} r$

rdit pr.f $r$ hd $d t$ [10] 
"The weaver in the workshop, he is worse off than a woman, with knees against his chest, he cannot breath air. if he skips a day of weaving, he is beaten fifty strokes, he gives food to the doorkeeper, to let him see the light of day" [11]

From all of the above, it appears that the job of the doorkeepers was important to the extent that characterizes their owners from other workers and craftsmen, and this is due to the nature of the work which requires that the incumbent to be with special specifications consistent with the nature of the work, such as vigilance and pay attention and perform the work with interest and to the fullest, so he can repel suspects and outlaws [12]. Maspero also emphasized when he describes the nature of the warehouses and silos in ancient Egypt on being surrounded by secured walls and on its entrances there were vigilant guards [13]. It should be noted that these descriptions which confer on them the strength and firmness has a popular view away of the scene of the tombs, here we find in one of the formulas that was mentioned in the temple of Seti I in Abydos and related with the pass ritual to the st-wrt hall:

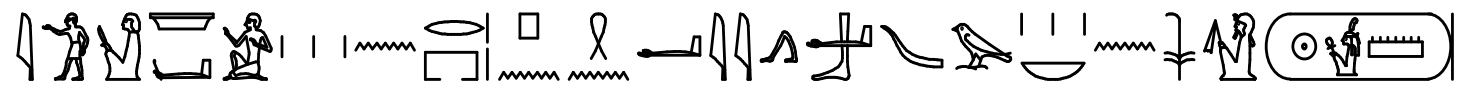

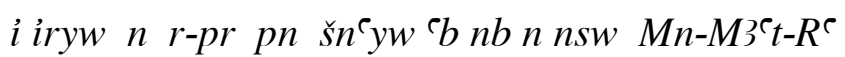

"Oh doorkeepers of this temple, who ward off all evil ones for king Menmaatre" [14]

\subsection{Scene from the tomb of Intf $\mathbb{X}_{\approx}$ m (TT 155)}

The Tomb of the herald of the king Tuthmosis III that called "Intef" lies in "Dra ${ }^{c}$ abu el-Naga" on the western bank at Thebes. he depicts on the wall which is located in the front hall to the right of the inside longitudinal hall, a scene representing four wine utensils bearers and behind them the supervisor, the first man of them pointed in wonder to the storage guard who was sleeping, fig. (1) [15]

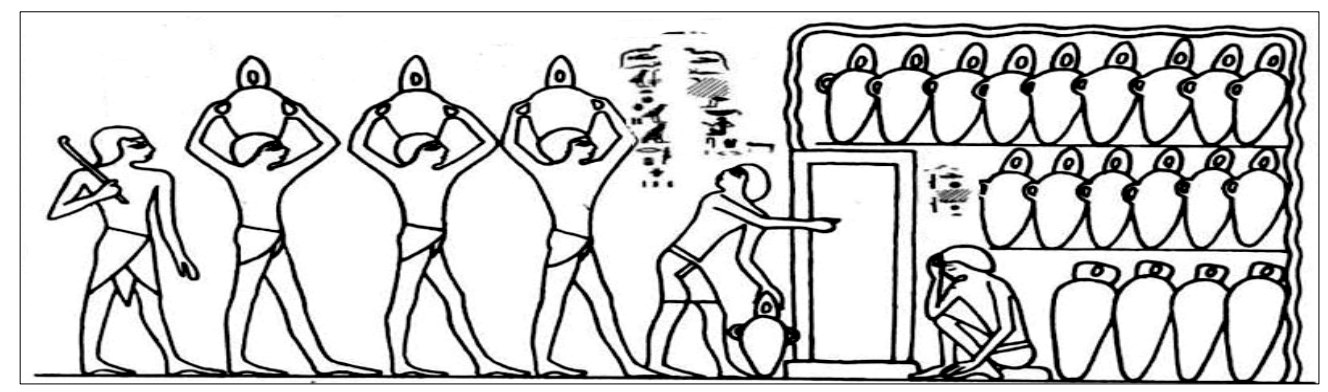

Figure (1) a drunk doorkeeper in the store

It has prevailed that the interpretation of this scene is only comically expression depicting the guard sleeping, and the purpose was to bring joy and happiness to the spirit of the tomb visitors, especially that the scene is in the front hall of the cemetery and known as "Almazar" [5]. In fact this scene does not represent the guard in the sleeping position, but the accompanying texts provide an explanation for what is happening in his flanks, we see that the first worker speaks to the followers saying: "the guard is sleeping", the other one replied saying: "he is drunk

from wine", at the same time the guard responds from the inside: "I am not asleep I am not asleep". There are two parts of evidence that emphasize the exclusion of the sleep status of this guard, the first is the existence of a text above his image, and this means according to technical rules in ancient Egypt that this text is out of his tongue, so he is still awake. The second is the unusual sitting position to express sleeping, where the usual way is to put the head to the knees with the intersection of the arms in front of the head $[16,17]$. So we can say that the 
guard - as the text referred - was very drunk and was not caring about his work, using his hand to rub his eyes expresses the loss of his consciousness, and for the purpose and the point from

\subsection{Scene from the tomb of Nfr-htp}

The tomb of the Chief scribe of Amun "Nefer-Hotep"- from the time of the king Amenhotep III- lies in "Khukha" in the western bank of Thebes [15], the scene shows a party in the royal palace garden, in order to reflect the passion of this unusual scene of the doorkeepers and the followed scenes in this research, will be answered at the end of the study.

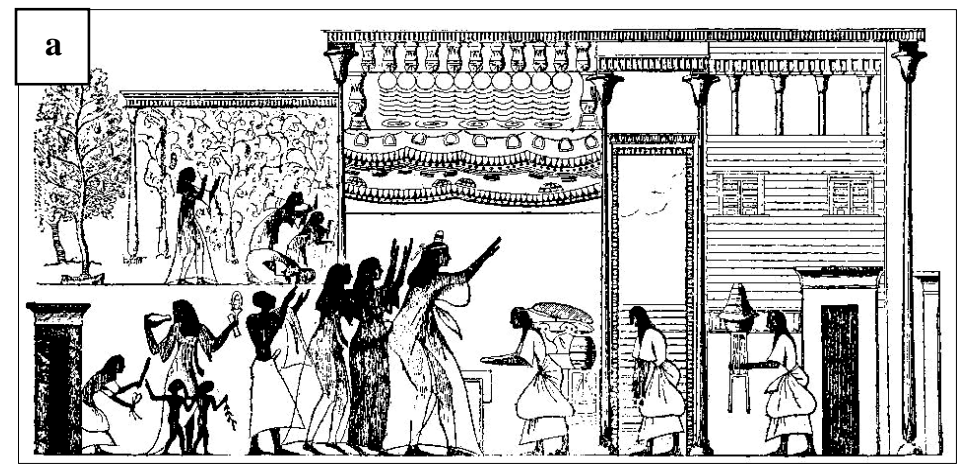

Figure (2) $\underline{\mathbf{a}}$. the royal palace garden $\underline{\mathbf{b}}$. the children awaken the doorkeeper by their noise

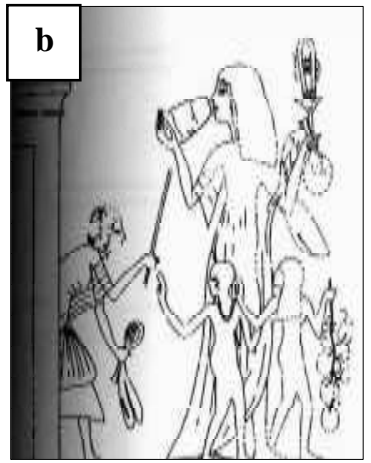

In this scene one of the ladies appear with two children playing with fruits and games, and this lady hold in one hand a sistrum and in the other hand holding a pot and drinking beer. It seems that the artist wanted to express the laziness of the guard or his usual sleeping in another way seemed here indirectly, he depicts the

2.3. Scene from the tomb of $T w t w$

guard as if he was going to punish the two children because they awaken him by their playing beside the noise of the sistrum which the mother holds, so he went out disturbed from his slumber chasing them $[5,20]$. Confirming by that the status of laziness and sleeping which accompany the doorkeepers in the ancient Egyptian art.

$\mathrm{He}$ bears the title the Chief Servitor in the time of "Akhenaton", which earned him a high position in the royal palace, we can notice that through his scenes in the cemetery which depicts him together with the king and his wife and also the size of the warehouses in his tomb which is likely to be either belonging to

\section{(Amarna)}

his home or the temples of "Atun", it is uncertain [17]. What we can observe in the scenes of these warehouses, regardless of its subordination, that they are depicted in many cases either empty without any guards, or the guard is sleeping with his head on his arms, fig. (3).

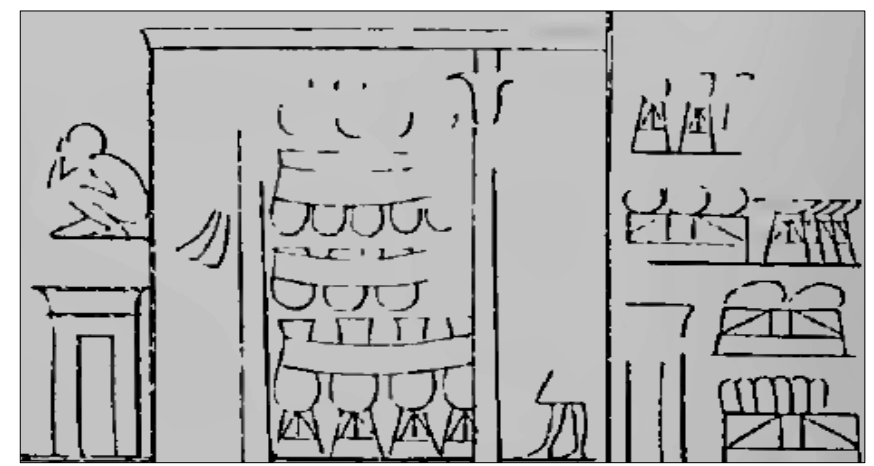

Figure (3) the doorkeeper sleep out of the warehouse 


\subsection{Scene from the tomb of $7 y 4$ 罂 44}

Iy was one of the most famous characters in the time of Amarna, he started his life as a soldier in the infantry army and vehicles, then became the leader of the army, after that he worked in the administrative jobs and priesthood, and there are likely to have a relation to the Pharaoh or his wife [21]. In the tomb of "Iy" appeared more than one scene depicts the Doorkeepers in various positions, but all of them meet in depicting the guard either in sleeping position or

\section{(Amarna)}

preoccupation in eating or in relaxing position [17]. The most important scene which represents the phenomenon that we are up to, is the scene which represents the special hall for El-Hareem and it consists of two rooms, in the first room appears an old lady with her two young girls playing with musical instruments, and in the other room there are four women eating and outside it depicts the guards in lazy positions, fig. (4) [17, 22].

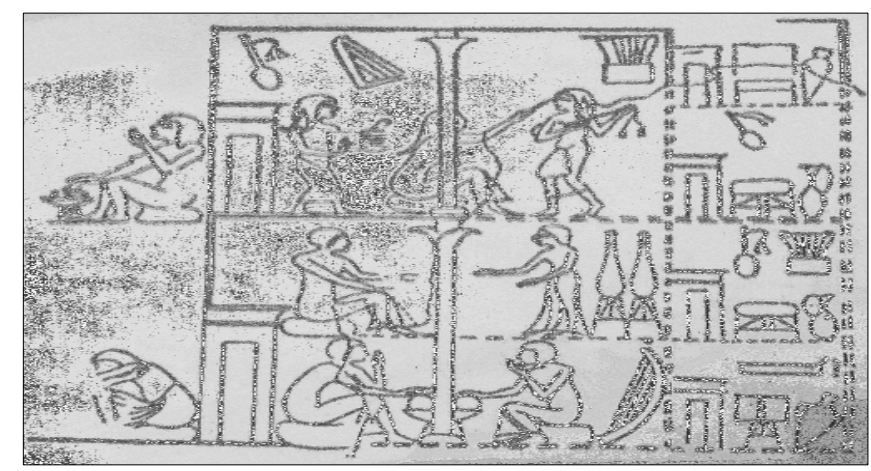

Figure (4) two doorkeepers, both don't care by guarding

In another scene, the artist depicts a doorkeeper standing not sleeping or distracting from work, the artist expresses the state of relaxation through the standing position which he raises one of his feet and puts it on the wall and stands on the other while speaking to someone else in front of him, fig. (5). Perhaps this position which the artist has expressed shows the state of relaxation and calm within his technical rules which he committed to achieve [16].

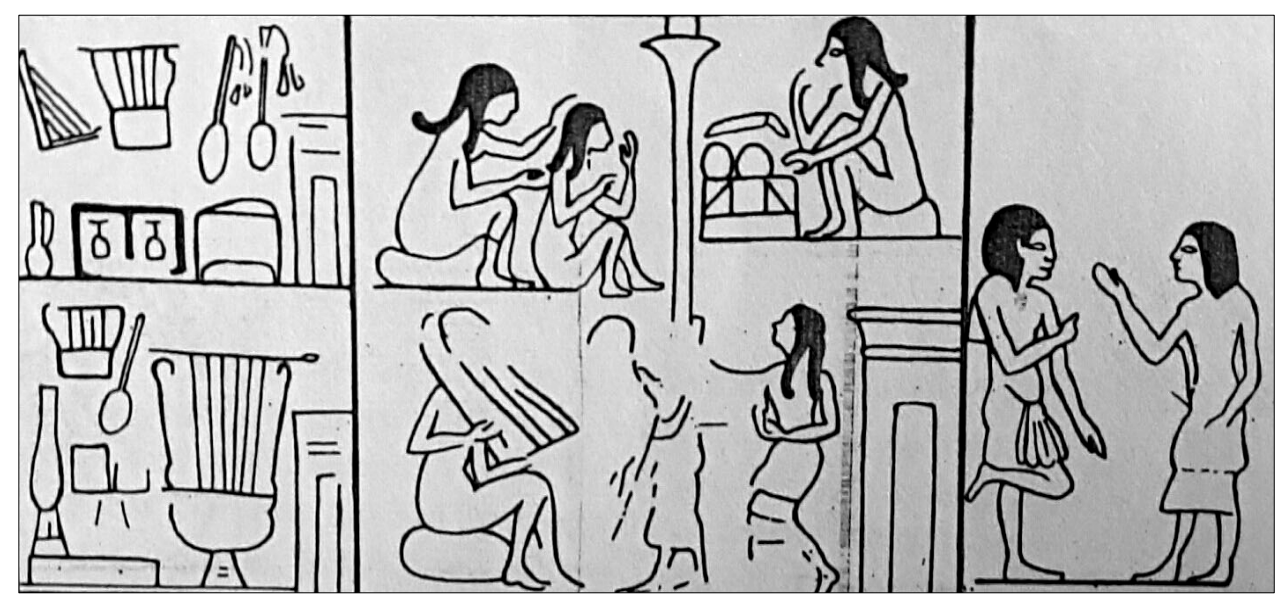

Figure (5) a doorkeeper standing in relaxation

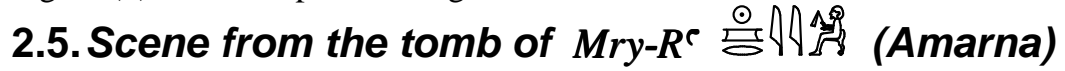

In this tomb appears a scene for a guard to one of the warehouses doors in the same shape of the previous one in the cemetery of "Iy", where we found a group of hard working servants transferring and filling pots of water and beside them in a form completely different from the vibrant scene which is full of movement and laziness the doorkeeper leaning on the door raising one of his feet in relaxing position and talking with one of the workers, fig.(6) [23]. 


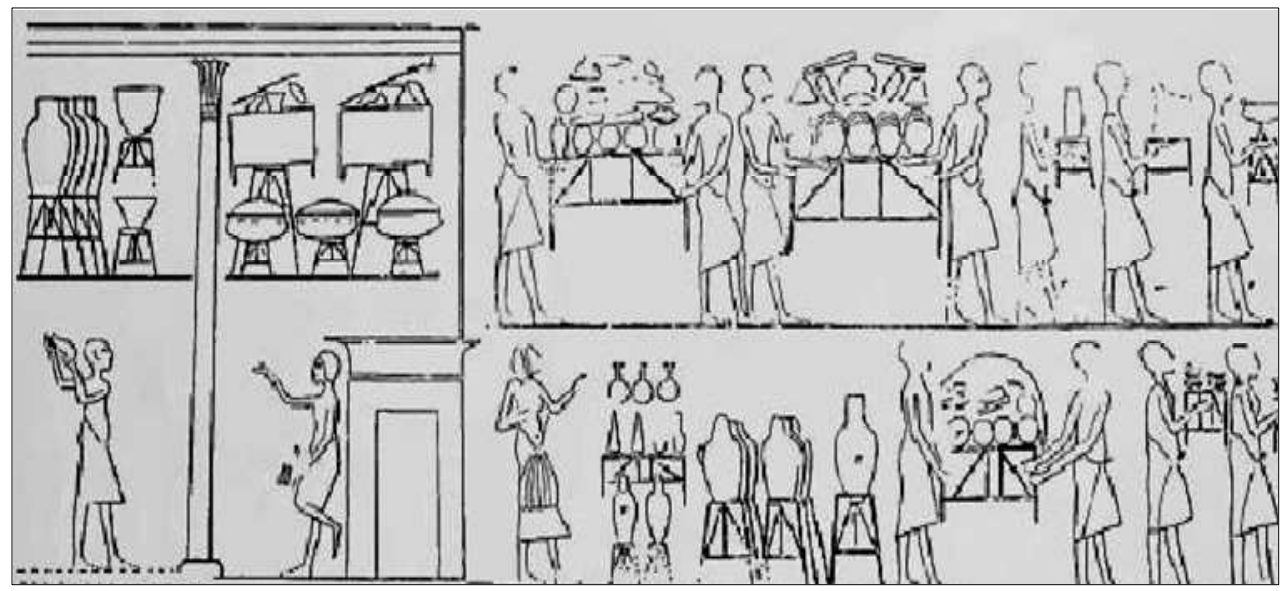

Figure (6) a doorkeeper in relaxing position

\subsection{Scene from the tomb of P3 nhsy}

This scene shows the buildings that are located near the temple and outside its walls, which may have been dedicated to the senior officials of the temple [23]., and we notice that next to one of these buildings and near to its gate there is a man standing holding a long stick in one hand and the other hand is stretched forward, fig. (7-a). In fact this scene is unfamiliar in the Amarna art scenes when depicting anyone of the general public. That was followed in the Amarna art that the servants and the followers are not depicted with sticks in their hands, but were carrying the feather if they were from the senior people or with free hands if they were from below.

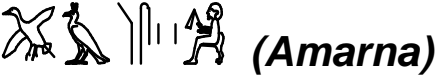

The question about this scene is: What is the need to depict the guard holding a stick which is unusual in depicting guards? To answer this question we must compare between the shape and the position of this guard and the image of the blind man from the tomb "Menna" (TT69), fig. (7-b) in the upper estate in the cemetery of "Sheikh Abdel Qurna" at Western Thebes [24]. Which appears in it the view of an old farmer holding a long stick in the form of "Was sign", in one of his hands and he put the other hand above a boy's head to lead him in walking and moving in an implicit expression for blind [25].

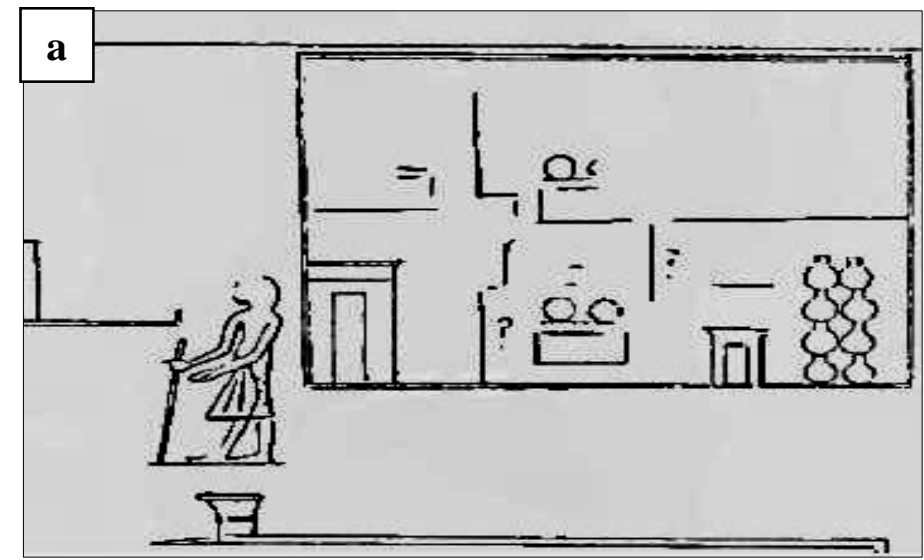

Figure (7) $\underline{\text { a. }}$ a doorkeeper seems blind

If we compare between the standing position and holding the stick, plus stretching the other hand forward, certainly this guard is blind; true that there is no one standing in front of him

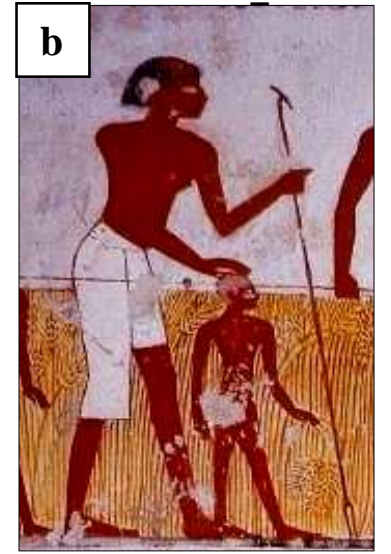

b. blind man

to lead him from his hand, but this situation expresses the loss of vision and the need for sensing during the movement. 


\subsection{Scene from a tomb of unknown owner (Saqqara)}

This scene depicts the doorkeeper sleeping and leaning on the door, standing on one foot in comically satirical way and he puts one of his hands under his head, like a pillow [5], and all

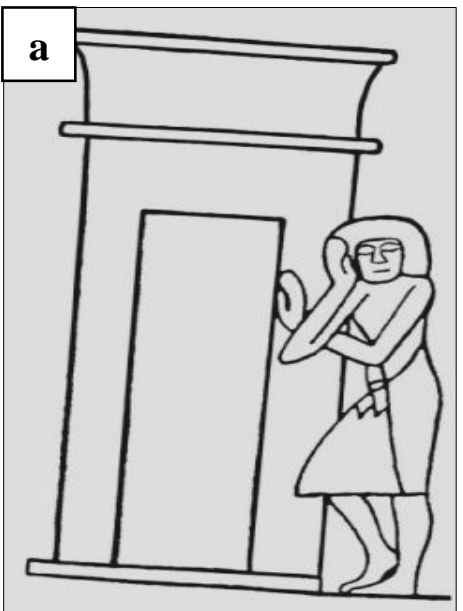

Figure (8-a \& b) a sleepy doorkeeper

The strange thing in this scene is that the artist depicts it from the front side to consist between the face and the body in unusual form in Egyptian art generally, and in the views of the doorkeepers particular, where it was used to depicts the guard with his back to the door [16]. The depicted pictures on the

\section{Reflect in Literature}

This phenom-enon has been observed in one of the literary works that are directly referred to it in various paragraphs as follows: * "the conflict between truth and lies" [27]. what refers to taking the blind man the job of the doorkeeper. * "the lie said to the Ennead gods; bring the truth here and blind his eyes and to become from now the doorman to my home" [28]. * "come on with us to see the blind man lying on the hill, let's bring him to become the doorman to our home" [28]. * "do you see this blind man sitting beside the door? this is your father" [28]. * "the eyes of the lie will be blinded and he will

\section{Discussion}

To explain this phenomenon we should keep in mind several important points which will lead us to understand that in the form of lax and surrender, fig. $(8-a, b)$ the artist used curved lines to express visually the form of lax and weakness [26].

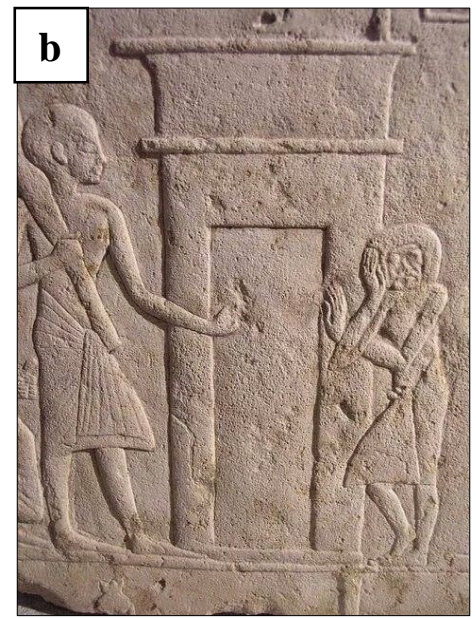

tomb's walls were not our only source to find out the aspects of the daily life in ancient Egypt, but the literary works which was written by folk as a parallel source that we cannot deny its importance, knowing the existence of some creativity and imagination that is acceptable in these works.

be the doorman to the truth home" [28]. * "his eyes will be blinded and he will be the doorman to truth home". [28]. This text has been written in the Ramesside period, in the second half of the time of the New kingdom, no wonder that this phenomenon has prevailed and entrenched in minds till it moved from the scenes and pictures of the tombs to the literary works, as in the case of the oldest ages when the professions satire texts spoke about the work nature of each craft separately as if it describes the scenes that was known from the walls of the tombs of the old and middle Kingdom.

the symbolic purpose behind this image, as follows: First: this phenomenon has appeared depicted in tombs than other 
architecture constructors; it was known that the ancient Egyptian believed that everything he recorded on the walls of his tomb, whether issues linked to the life or the other world, to serve the funeral purposes in the first place. When we find him depicts banqueting and parties that means he expresses the life of luxury and pleasure in the other world, the same when he depicts the fields and orchards, he aims to move the image itself to the heavens of the other world after it was recite by some magical formulas and hymns [29]. So, no wonder about the absence of this phenomenon the subject of the study about the scenes of the divine temples, where it was dedicated to serve life purposes only.

Second: this phenomenon became clearly visible in the New Kingdom and the subsequent eras, we did not find any evidence for it before this era and that can be explained by its conjunction with the appearance of the depicted book of the dead, after it was pyramids texts and coffin texts as well, it was only written texts. It has been shown from the scenes of books of the dead that the gates and doorways which the deceased had to cross play the main role, which can be clearly understood in the book of gates.

Third: it was appeared in the book of gates chapters 144-147 in a depicted form a group of guards with legendary shapes, each of them has two or three followers or assistants combine the bodies of humans and heads of animals or predatory reptiles or demons and holding with their hands shapes of knives or snakes, fig. (9) The deceased should crosses all of them after he succeeds in the recitation of the formula assigned to each gate [4]. Otherwise the deceased will face the threat of extinction if the guards prevented him from crossing the gate, which means for him the deprivation of eternity. True that these gates and its guards have been known since the old kingdom in the pyramids texts [30], and also since the middle kingdom in the coffin texts [31], but it did not entrenched in mind and reached the maximum importance except after it has been depicted in the books of the dead starting from the New kingdom.

Fourth: there are doorkeepers in the other world bears the name špy $\square \Delta 4$ which means the blind, in the book of gates [32].

Fifth: there were many rules and technical principles control the artist during his implementation of the scenes in the tombs, but these rules did not found in the scenes and inscriptions of temples and other mundane chores, in line with what the funerary art believed while depicting the shapes and embodies them as a new creating process [27]. For example, the ancient Egyptian had to be careful of being depicted in his tomb with a handicap or infirmity not to be resurrects with it in the other world. Also he had to secure himself from the human enemies and animals not to obstruct his way in the nether world, we find him depicted the prisoners handcuffed behind their backs, in the time that it could be possible to depict them in the temples free in the form of hit and run. Besides that, there were dangerous animals or forbidden in his belief, it appeared in the range of hunting and fishing [27], it was impossible to appear even in the "dedicated" picture in the texts written in Hieroglyphics, so either he was searching for alternative or to depict it tied or with broken neck.

Sixth: the ancient Egyptian realizes the dangerous of the other world's gates and its guards as well since the era of writing the coffin texts; he should always reciting incantations that enables him to get in and out without facing the guards. We find one of the dead directing his speech to the other world's gates saying: "Greeting for you unknown and holy gates, may you save this person from every harm and evil of strongmen in front of you" [33] means by "In front you" guards of course. 


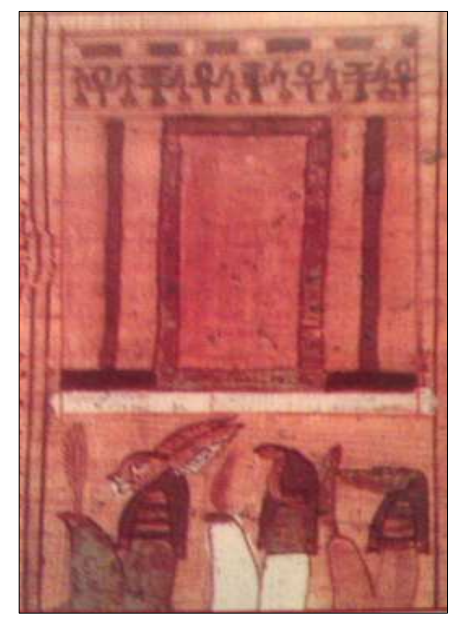

Figure (9) armed doorkeepers in the book of the dead

\section{Conclusion}

From all of the above we can say that, from the beginning of the New Kingdom, and after the ancient Egyptian realized as a fact, that the nether world is only a set of gates on which tough guards stands and he should face them and deal with them in order to let him pass, and to enjoy an amount of freely movement and repeated getting in and out to share "Re" in his journey, so it was necessary when he depicts the shape of the gates in his daily life, whatever its function or use, to depict in its guard whom his qualities will move to the doorkeepers of the other world's gates the lax and omissions so he can pass easily without any obstacles and ensure the freely movement through the gates besides the eternal life. So he resorted to two main ways in depicting the entrances and gates: either to leave it free from guards, or to present the guard in one of the previous cases, exactly as he depicts the offering table with different kinds of food so he would be blessed with the same in the other world, confirming the deep concept that was included in the Egyptian graphic art which was the connection between the search for the aesthetic meaning and the desire to prepare for the eternal life that he wishes and strives to achieve.

\section{References}

[1] Aldred, C., (1951). New kingdom art in ancient Egypt, Alec Tiranti LTD, London.

[2] Hornung, E., (1963). Das amduat, die Schrift des Verborgenen Raumes, Harrassowitz, Wiesbaden.

[3] Qanawati, N., (1987). The Tomb and its Significant in Ancient Egypt, Dar al kuttub, Cairo.

[4] Wells, R., (1993). Origin of the hour and gates of the Duat, SAK, Vol. 20, pp. 305-326.

[5] Houlihan, P., (2001). Wit and humor in ancient Egypt, Stacey International, London.

[6] VerSteeg, R., (2002). Law in ancient Egypt, Carolina Academic Press, Durham.

[7] David, R., (1986). The pyramid builders of ancient Egypt: A modern investigation of pharaoh's workforce, Routledge, New York.
[8] Bierbrier, M., (2003). The tomb builders of the Pharaohs, The American University in Cairo Press, Cairo.

[9] El-Saady, H., (1998). Consideration on bribery in ancient Egypt, $S A K$, Vol. 25, pp.295-304.

[10] Brunner, H., (1944). Die lehre des cheti, Sohnes des duauf, Verlag J. J. Augustin, Hamburg.

[11] Lichtheim, M., (1973). Ancient Egyptian literature, A book of reading, Vol. 1, University of California press, Los Angles.

[12] Strouhal, E., (1992). Life of the ancient Egyptians, University of Oklahoma press, London.

[13] Maspero, G., (1895). Manual of Egyptians archaeology and guide to study of antiquities in Egypt, A. Picard \& Kaan, Paris.

[14] Nilson, H., (1949). The rite of 'bringing the foot' as portrayed in 
temple reliefs, JEA, Vol. 35, pp.82-86.

[15] Porter, B \& Moss, R., (1970). Topographical bibliography of ancient Egyptian Hierogyphic texts, reliefs, and paintings, Vol. 1, Part 1, Griffith Institute, Oxford.

[16] Schäfer, H., (1974). Principles of Egyptian art, Griffith Institute, Oxford

[17] Davies, N., (1908). The rock tombs of El-Amarna, Vol. VI, William Clowes \& sons, London.

[18] Erman, A \& White, J., (1971). Life in ancient Egypt, Dover Publications, NY.

[19] Wilkinson, A., (1994). Symbolism and design in ancient Egyptian gardens, Garden History, Vol. 22 (1), pp. 1-17.

[20] Davies, N., (1933). The tomb of Neferhotep at Thebes, Arno Press, New York.

[21] Porter, B \& Moss, R., (1934). Topographical bibliography of ancient Egyptian Hierogyphic texts, reliefs, and paintings, Vol. $1 \mathrm{~V}$, Griffith Institute, Oxford.

[22] Wenig, S., (1969). The woman in Egyptian art, McGraw-Hill, Leipzig.

[23] Davies, N., (1905). The rock tombs of El-Amarna, Vol. II, Gilbert and Rivington Limited, London.
[24] Campbell, C., (1910). Two princes Theban tombs, University of Michigan Library, London.

[25] Wreszinski, W., (1923). Atlas zur Altägyptischen kulturgeschichte, Vol. I, J. C. Hinrichs, Leipzig.

[26] La Louette, C., (1992). L'art et la vie dans l'Egypte pharaonique, Fayard, Paris.

[27] Gardiner, A., (1932). Late Egyptian stories, Fondation Egyptologique Reine Elisabeth, Bruxelles.

[28] Lichtheim, M., (1976), Ancient Egyptian literature, Vol. II, University of California press, Berkeley, Los Angles.

[29] Franke, D., (2003). The middle kingdom offering formulas: A Challenge, JEA, Vol. 89, pp. 3957.

[30] Faulkner, R., (1969). The ancient Egyptian pyramid texts, Oxford University Press, Oxford.

[31] Faulkner, R., (1973). The ancient Egyptian coffin texts, I, Aris \& Philips, England.

[32] Piankoff, A., (1954). The tomb of Ramesses IV Texts, Pantheon Books, New York.

[33] Faulkner, R., (1978). The ancient Egyptian coffin texts, III, Aris \& Philips, England. 